\title{
Determination of organochlorine pesticide residues in honey from the central zone of Portugal and the Valencian community of Spain ${ }^{\text {is }}$
}

\author{
C. Blasco ${ }^{\mathrm{b}}$, C.M. Lino ${ }^{\mathrm{a}, *}$, Y. Picó ${ }^{\mathrm{b}}$, A. Pena ${ }^{\mathrm{a}}$, G. Font ${ }^{\mathrm{b}}$, M.I.N. Silveira ${ }^{\mathrm{a}}$ \\ ${ }^{a}$ Celeste de Matos LINO, Group of Bromatology—CEF, Laboratory of Bromatology, Faculty of Pharmacy, \\ University of Coimbra, 3000-295 Coimbra, Portugal \\ ${ }^{\mathrm{b}}$ Laboratori de Bromatologia i Toxicologia, Facultat de Farmàcia, Universitat de València, Burjassot, València, Spain
}

Received 8 March 2004; received in revised form 30 June 2004; accepted 15 July 2004

\begin{abstract}
In this study nine organochlorine pesticide residues $(\alpha-, \beta-$, and $\gamma$-hexachlorocyclohexane $(\mathrm{HCH})$, hexachlorobenzene (HCB), aldrin, $p, p^{\prime}$-DDE, $p, p^{\prime}$-DDD, $o, p^{\prime}$-DDT, and $p, p^{\prime}$-DDT) in forty nine samples of honey collected from markets of Portugal and Spain during 2001 and 2002, respectively, were evaluated. For this evaluation, three analytical procedures were studied. The analytical procedure, based on LLE extraction with ethyl acetate followed by gas chromatography-electron-capture detection (GC-ECD) for quantification, and mass spectrometry (GC-MS) for confirmation, has been selected. Recoveries of spiked samples ranged from $68 \%$, for $\beta-\mathrm{HCH}$, and $126 \%$ for $p, p^{\prime}$-DDT, for fortification levels between 10 and $100 \mu \mathrm{g} / \mathrm{kg}$, and $64 \%$, for $\alpha-\mathrm{HCH}$, and $143 \%$ for $\gamma$-HCH for fortification levels between 20 and $200 \mu \mathrm{g} / \mathrm{kg}$. Limits of quantification, using GC-ECD, were from 0.01 and $0.10 \mathrm{mg} / \mathrm{kg}$, and limits of detection between 0.001 and $0.02 \mathrm{mg} / \mathrm{kg}$. Fourteen Valencian samples were contaminated, containing residues of HCB or/and HCH isomers. The frequency of detection was $56 \%$ for Spanish samples. In Portugal, 23 samples were contaminated, what means $95.8 \%$. In Spanish samples, concentrations range from nd to $0.03 \mathrm{mg} / \mathrm{kg}$ for $\mathrm{HCB}$, and nd to $2.24 \mathrm{mg} / \mathrm{kg}$ for $\mathrm{HCH}$-total. The mean concentration and standard deviation were $0.017 \pm 0.011 \mathrm{mg} / \mathrm{kg}$ for $\mathrm{HCB}$, and $0.579 \pm 0.747 \mathrm{mg} / \mathrm{kg}$ for $\mathrm{HCH}$-total, contributing the $\gamma$ isomer with the highest values. The samples from Portugal showed higher levels. Levels of HCB ranged from nd to $0.39 \mathrm{mg} / \mathrm{kg}$. HCH-total ranged from nd to $4.86 \mathrm{mg} / \mathrm{kg}$, and DDT-total from nd to $0.658 \mathrm{mg} / \mathrm{kg}$. Mean concentration and standard deviation were $0.09 \pm 0.116 \mathrm{mg} / \mathrm{kg}$ for $\mathrm{HCB}, 1.357 \pm 1.30 \mathrm{mg} / \mathrm{kg}$ for $\mathrm{HCH}$-total, and $0.143 \pm 0.193 \mathrm{mg} / \mathrm{kg}$ for DDT-total.
\end{abstract}

(C) 2004 Elsevier B.V. All rights reserved.

Keywords: Organochlorine; Pesticides

\section{Introduction}

The occurrence of organochlorine compounds in the food chain has already been reported in several studies. This class of organic compounds constitutes one of the most important groups of dangerous organic contaminants. The environmental contamination by persistent organochlorine pesticide

\footnotetext{
is Presented at the 3rd Meeting of the Spanish Association of Chromatography and Related Techniques and the European Workshop: 3rd Waste Water Cluster, Aguadulce (Almeria), 19-21 November 2003.

* Corresponding author. Tel.: +351 239859994; fax: +351 239827126.

E-mail address: cmlino@ci.uc.pt (C.M. Lino).
}

(OCPs) residues has been widely documented in several countries, such as Portugal and Spain in medicinal plants, water, milk, and biological fluids [1-4]. Due to its lipophilic nature, OCPs enter into the food chain by accumulating in fats, but can also be present in non-fatty products, even those which have not been treated directly with them [5]. They can be present in honey because of the plant treatment or by migration from wax to honey. Since honeybees travel long distances and come close to many plants, honey may be an easily accessible environmental pollution indicator $[6,7]$. Pesticide determination in bee products is necessary to monitor contamination and guarantee consumer health [7]. Honey is a natural product that must be free of any chemical 
contaminants and safe for human consumption, because in some countries is traditionally used in child, old and ill people and its quality must be proved [8].

Many methods have been reported for the determination of pesticides in honey. However, these samples pose substantial analytical problems, particularly to high percentage of sugar [7] or, in some cases, intensive coloration due to pigments. Most methods used for OCPs are based on liquid-liquid extraction (LLE) performed with water non-miscible solvents, such as ethyl acetate [9], petroleum ether [10], or $n$-hexane [11,12], dichloromethane [13], or miscible solvents, such as methanol $[8,14]$. Solid-phase extraction (SPE) with $\mathrm{C}_{18}$ cartridge [8], Florisil [11], polystyrene-divinylbenzene sorbent copolymer [15], solid-phase microextraction (SPME) [16] has also been applied to honey samples. Sometimes, after LLE extraction a clean-up with different adsorbents may be necessary, Florisil $[10,12,14]$ or silica or activated carbon and silica gel [13]. GC-ECD has been widely applied as the preferred technique for the identification and quantification of OC pesticides [8-17] due its high sensitivity to molecules that contains electronegative atoms, but requires subsequent confirmation by GC-MS in mode electron impact in which molecules are bombarded by high energy, $70 \mathrm{eV}$ [7].

The purpose of this work was to develop a rapid and liquid-liquid extraction method for the analysis of nine organochlorine pesticide residues, $\alpha-, \beta-$, and $\gamma-$ hexachlorocyclohexane (HCH), hexachlorobenzene (HCB), aldrin, $p, p^{\prime}$-DDE, $p, p^{\prime}$-DDD, $o, p^{\prime}$-DDT, and $p, p^{\prime}$-DDT) in honey followed by GC-ECD and GC-MS, and evaluate the level of contamination with OCP residues.

\section{Experimental}

\subsection{Chemicals}

Pesticide standards were purchased from Dr. Eherstörfer (Augsburg, Germany). Pethroleum ether, diethyl ether, $n$ hexane, and ethyl acetate (for residue analysis) were obtained from Carlo Erba (Milan, Italy). Stock solution of each pesticide was prepared separately at $500 \mathrm{mg} / 1$ in $n$-hexane, except for $\beta-\mathrm{HCH}$, which was prepared in $n$-hexane-acetone (95:5, $\mathrm{v} / \mathrm{v}$ ), and $\gamma-\mathrm{HCH}$, which was supplied at a concentration of $10 \mu \mathrm{g} / \mathrm{ml}$ in cyclohexane. Standard solutions were prepared at $10 \mathrm{mg} / \mathrm{l}$, and then stored at $4{ }^{\circ} \mathrm{C}$. Working solutions were prepared between $0.2 \mu \mathrm{g} / \mathrm{ml}$ for HCB and $2 \mu \mathrm{g} / \mathrm{ml}$ for $p, p^{\prime}$ DDT.

Deionized water was prepared from a Milli-Q system (Millipore, Bedford, MA, USA). Florisil was obtained from Fluka (USA), and activated at $300^{\circ} \mathrm{C} / 3 \mathrm{~h}$ in a furnace, cooled in a dessicator, and deactivated to $2 \%$ with water.

\subsection{Apparatus}

One rotary vacuum evaporator from Heidolph VV 2001 (Kelheim, Germany) and two mechanical shakers for sep- aratory funnels (Agitelec, J. Toulemond, Paris; Edmund Bühler 7400 Tubigen KL2, Germany) were used. Glass minicolumns, $100 \mathrm{~mm} \times 8 \mathrm{~mm}$ i.d., obtained from Normax (Portugal) were used.

\subsection{Sampling}

A total of forty-nine honey samples were purchase in different local markets, 25 from Valencian community in Spain, and 24 from central zone of Portugal, collected in November 2002 and during 2001, respectively. Honey samples were provided to the markets from the beekeeper associations of these respective areas ensuring that they were provided in the zone of study.

\subsection{Recoveries}

For recovery studies, in method $1,0.25 \mathrm{ml}$ of a working solution containing between $0.2 \mu \mathrm{g} / \mathrm{ml}$ for HCB and $2 \mu \mathrm{g} / \mathrm{ml}$ for $p, p^{\prime}$-DDT were added to $5 \mathrm{~g}$ of honey, and allowed to stand for $15 \mathrm{~min}$ before extraction, for three replications. For method 2, a similar procedure was followed, adding $0.2 \mathrm{ml}$ of the working solution to $4 \mathrm{~g}$ of honey. In method 3, $0.25 \mathrm{ml}$ were added to $5 \mathrm{~g}$. For method 1, another fortification level was evaluated. In this case, $0.5 \mathrm{ml}$ of the working solution containing between $0.2 \mu \mathrm{g} / \mathrm{ml}$ for HCB and $2 \mu \mathrm{g} / \mathrm{ml}$ for $p, p^{\prime}$ DDT were added to $5 \mathrm{~g}$ of honey, over three replications.

\subsection{Extraction and clean-up procedures}

\subsubsection{Method 1}

Five grams of honey was dissolved with $50 \mathrm{ml} 4 \%$ aqueous solution of sodium sulphate and extracted with three portions of ethyl acetate $(20,15$, and $15 \mathrm{ml})$. When emulsion is formed it was broken centrifuging at $3000 \mathrm{rpm}$ for $10 \mathrm{~min}$. The organic phase was filtered by anhydrous sodium sulphate, and concentrated to $2.5 \mathrm{ml}$ for analysis, in graduated centrifuge tube, under nitrogen.

\subsubsection{Method 2}

Four grams of honey was dissolved with $25 \mathrm{ml}$ of deionized water and extracted with three portions of $15 \mathrm{ml}$ light petroleum by mechanical shaking at $55 \mathrm{rpm}$ for $15 \mathrm{~min}$. When emulsion is formed it was quickly broken centrifuging at $3000 \mathrm{rpm}$ for $10 \mathrm{~min}$. The organic phase was filtered by anhydrous sodium sulphate, and concentrated to $1 \mathrm{ml}$ for analysis. The concentrated extract was loaded onto a minicolumn filled with Florisil ( $2 \mathrm{~g})$ and anhydrous sodium sulphate $(1 \mathrm{~g})$, prerinsed with $10 \mathrm{ml}$ light petroleum. The elution was performed with $25 \mathrm{ml}$ of $5 \%$ of diethyl ether in petroleum ether. The eluate was concentrated to dryness in graduated centrifuge tube and redissolved in $500 \mu l$ of $n$-hexane.

\subsubsection{Method 3}

Five grams of honey was dissolved with $10 \mathrm{ml}$ of deionized water and extracted with $3 \times 5 \mathrm{ml}$ of $n$-hexane by magnetic 
stirring for $15 \mathrm{~min}$. When emulsion is formed it was broken centrifuging at $3000 \mathrm{rpm}$ for $10 \mathrm{~min}$. The organic phase was filtered by anhydrous sodium sulphate, and concentrated to $1 \mathrm{ml}$. The concentrated extract was loaded onto a minicolumn filled with Florisil ( $2 \mathrm{~g}$ ) and anhydrous sodium sulphate ( $1 \mathrm{~g})$, pre-washed with $10 \mathrm{ml} n$-hexane. The pesticides were eluted from the column with $25 \mathrm{ml}$ of $15 \%$ of diethyl ether in $n$ hexane. The eluate was concentrated to $1 \mathrm{ml}$, under a steam of nitrogen.

\subsection{Gas chromatography with electron-capture detector}

A Carlo Erba Mega HRGC 5300 equipped with ${ }^{63} \mathrm{Ni}$ electron-capture detector was used for quantification. One fused silica capillary column $(30 \mathrm{~m} \times 0.25 \mathrm{~mm} \times 0.25 \mu \mathrm{m}$ with chemically bonded phase DB-5 (J\&W Scientific)) was used. One microliter $(\mu 1)$ of sample was injected in the splitless mode and the splitter was opened after $60 \mathrm{~s}$. Chromatographic conditions were at temperature $280{ }^{\circ} \mathrm{C}$ for the detector, $220^{\circ} \mathrm{C}$ for the injector, and $150^{\circ} \mathrm{C}$ held for $1 \mathrm{~min}$ and programmed at $10^{\circ} \mathrm{C} / \mathrm{min}$ to $210^{\circ} \mathrm{C}$ held for $1 \mathrm{~min}$ and programmed at $3{ }^{\circ} \mathrm{C} / \mathrm{min}$ to $230^{\circ} \mathrm{C}$, held for $5 \mathrm{~min}$ and finally programmed at $3{ }^{\circ} \mathrm{C} / \mathrm{min}$ to $250{ }^{\circ} \mathrm{C}$, held for $3 \mathrm{~min}$. Gases used were: carrier gas helium $\mathrm{N} 60$ carrier at $2 \mathrm{ml} / \mathrm{mim}$, split valve $100 \mathrm{ml} / \mathrm{min}$, purge valve $2 \mathrm{ml} / \mathrm{min}$, make-up gas, nitrogen at $120 \mathrm{kPa}$. One integrator Spectra-Physics 4270 (Darmstadt, Germany) was used to integrate peak areas. Quantifications were made accordingly Lino et al. [1], using the external standard method, comparing peak areas of the standard with the peaks of extracts at the same retention time.

\subsection{Gas chromatography with mass spectrometry}

GC confirmatory analysis was carried out on a Trace GC-MS 2000 (Thermo Finnigan, Manchester, UK) system with Xcalibur software-based data acquisition. The injector temperature was $220^{\circ} \mathrm{C}$ and the detector one was $280^{\circ} \mathrm{C}$. Sample was injected in the splitless mode and the splitter was opened after $60 \mathrm{~s}$. A fused silica capillary column $(30 \mathrm{~m}$ $\times 0.25 \mathrm{~mm} \times 0.25 \mu \mathrm{m}$ with chemically bonded phase DB-5) was used. This temperature was $150^{\circ} \mathrm{C}$ held for $1 \mathrm{~min}$ and programmed at $10^{\circ} \mathrm{C} / \mathrm{min}$ to $210^{\circ} \mathrm{C}$ held for $1 \mathrm{~min}$ and programmed at $3{ }^{\circ} \mathrm{C} / \mathrm{min}$ to $230^{\circ} \mathrm{C}$, held for $5 \mathrm{~min}$ and finally programmed at $3{ }^{\circ} \mathrm{C} / \mathrm{min}$ to $250{ }^{\circ} \mathrm{C}$, held for $3 \mathrm{~min}$. The MS ionization potential was $70 \mathrm{eV}$, the temperatures were as follows: ion source $250{ }^{\circ} \mathrm{C}$, transfer line $200^{\circ} \mathrm{C}$ and analyser $230^{\circ} \mathrm{C}$. Analysis was performed in the selected-ion monitoring (SIM) mode monitoring specific ions of each analyte as it is shown in Table 1. The most intense ion was used for quantification and the second and third ion for confirmation.

\section{Results and discussion}

\subsection{Remarks on methods}

The ECD system was linear in the range between LOQ and 100 LOQs and correlations were better than 0.994, except for $\beta-\mathrm{HCH}$, that was 0.972 .

Repeatibility and reprodutivity were calculated making three replicate determinations at limit of quantification levels in the same day with relative standard deviations (R.S.D.s) of $5-15 \%$, and in five days with a R.S.D. of 7-14\%.

The MS detector was linear in the concentration range between LOQ and 100 times LOQ and correlations were better than 0.999 . Repeatibility and reprodutivity were calculated as it has been previously described with R.S.D.s from 6 to $9 \%$ and 12 to $15 \%$, respectively.

With a view to obtaining a more adequate method for the quantification of the organochlorine pesticides three methods were evaluated. Untreated samples and fortified honey samples in the range of $10-100 \mu \mathrm{g} / \mathrm{kg}$ were analysed by three different methods, using LLE with different solvents, ethyl acetate, light petroleum, or $n$-hexane. When light petroleum or $n$-hexane was used, a clean-up procedure with Florisil was also applied. Recoveries and relative standard deviation obtained with the three methods are shown in Table 2. The best results, for fortification levels between 10 and $100 \mu \mathrm{g} / \mathrm{kg}$, were obtained dissolving honey in sodium sulphate and extracting with ethyl acetate (method 1). Results obtained for dissolution in water, extraction with petroleum ether, and clean-up with Florisil were not adequate. Recovery values are very low for $\alpha-\mathrm{HCH}, \beta-\mathrm{HCH}, o, p^{\prime}$-DDT and $p, p^{\prime}$-DDT, and very high for HCB. Using $n$-hexane, as extraction solvent, also the recoveries, for all compounds,

Table 1

SIM conditions of organochlorine pesticides detected by GC-MS

\begin{tabular}{|c|c|c|c|c|c|c|}
\hline Peak number & Pesticides & $t_{\mathrm{R}}(\min )$ & $\begin{array}{l}\text { Molecular } \\
\text { mass }\end{array}$ & $\begin{array}{l}\text { Quantitation } \\
\text { ions }(\mathrm{m} / \mathrm{z})\end{array}$ & $\begin{array}{l}\text { Confirmation ions } \\
\text { no. } 1(\mathrm{~m} / \mathrm{z})\end{array}$ & $\begin{array}{l}\text { Confirmation ions } \\
\text { no. } 2(\mathrm{~m} / \mathrm{z})\end{array}$ \\
\hline 1 & $\alpha-\mathrm{HCH}$ & 12.93 & 288 & 181 & 109 & 219 \\
\hline 2 & $\mathrm{HCB}$ & 13.33 & 282 & 284 & 282 & 286 \\
\hline 3 & $\beta-\mathrm{HCH}$ & 13.84 & 288 & 109 & 181 & 219 \\
\hline 4 & $\gamma-\mathrm{HCH}$ & 14.18 & 288 & 109 & 181 & 219 \\
\hline 5 & Aldrin & 19.44 & 362 & 263 & 261 & 265 \\
\hline 6 & $p, p^{\prime}-\mathrm{DDE}$ & 25.62 & 316 & 246 & 318 & 316 \\
\hline 7 & $p, p^{\prime}-\mathrm{DDD}$ & 28.08 & 318 & 235 & 199 & 165 \\
\hline 8 & $o, p^{\prime}-\mathrm{DDT}$ & 29.09 & 352 & 235 & 270 & 272 \\
\hline 9 & $p, p^{\prime}-\mathrm{DDT}$ & 31.74 & 352 & 235 & 270 & 272 \\
\hline
\end{tabular}


Table 2

Recoveries obtained with the three methods in honey [mean \pm R.S.D. (\%) $(n=3)]$

\begin{tabular}{llcccc}
\hline Peak no. & Pesticide & $\begin{array}{c}\text { Fortification } \\
\text { level }(\mu \mathrm{g} / \mathrm{kg})\end{array}$ & Method 1 & Method 2 & Method 3 \\
\hline 1 & $\alpha-\mathrm{HCH}$ & 25 & $82 \pm 10$ & $25 \pm 12$ & $235 \pm 23$ \\
2 & $\mathrm{HCB}$ & 10 & $110 \pm 8$ & $702 \pm 1012$ & $153 \pm 17$ \\
3 & $\beta-\mathrm{HCH}$ & 50 & $68 \pm 21$ & $43 \pm 15$ & $131 \pm 21$ \\
4 & $\gamma-\mathrm{HCH}$ & 25 & $82 \pm 10$ & $84 \pm 35$ & $137 \pm 16$ \\
5 & Aldrin & 50 & $111 \pm 31$ & $75 \pm 34$ & $128 \pm 5$ \\
6 & $p, p^{\prime}-\mathrm{DDE}$ & 50 & $77 \pm 6$ & $73 \pm 36$ & $150 \pm 25$ \\
7 & $p, p^{\prime}-\mathrm{DDD}$ & 50 & $86 \pm 16$ & $75 \pm 38$ & $140 \pm 15$ \\
8 & $o, p^{\prime}-\mathrm{DDT}$ & 50 & $85 \pm 22$ & $51 \pm 24$ & $170 \pm 25$ \\
9 & $p, p^{\prime}$-DDT & 100 & $126 \pm 17$ & $53 \pm 25$ & $168 \pm 37$ \\
\hline
\end{tabular}

are inconsistently higher, probably due to matrix effects. The method 1 was also applied to spiked samples between 20 and $200 \mu \mathrm{g} / \mathrm{kg}$. Table 3 gives recoveries of honey samples spiked at two levels, R.S.D., LODs, and LOQs. The mean recoveries vary between $68 \%$, for $\beta-\mathrm{HCH}$, and $126 \%$, for $p, p^{\prime}$-DDT for fortification levels between 10 and $100 \mu \mathrm{g} / \mathrm{kg}$, and $64 \%$, for $\alpha-\mathrm{HCH}$, and $143 \%$ for $\gamma-\mathrm{HCH}$ for fortification levels between 20 and $200 \mu \mathrm{g} / \mathrm{kg}$. R.S.D.s ranged from 6 and $31 \%$ for the first fortification level, and from 1 and $23 \%$ for the second one. The LODs and LOQs obtained by GC-ECD ranged from 0.001 to $0.02 \mathrm{mg} / \mathrm{kg}$ and from 0.01 to $0.10 \mathrm{mg} / \mathrm{kg}$, respectively, whereas by GC-MSD, the LODs were from were $0.003-0.01 \mathrm{mg} / \mathrm{kg}$ and the LOQs $0.01-0.04 \mathrm{mg} / \mathrm{kg}$.

\subsection{Application to real samples}

This study shows that 14 Valencian samples were contaminated, containing residues of $\mathrm{HCB}$ or/and $\mathrm{HCH}$ isomers. The frequency of detection was $56 \%$ for Spanish samples. In Portugal, 23 samples were contaminated, what means $95.8 \%$. Only aldrin residues were not detected in Portuguese samples.

Table 4 shows the results obtained with Portuguese and Valencian samples. In Spanish samples, concentrations range from nd to $0.03 \mathrm{mg} / \mathrm{kg}$ for $\mathrm{HCB}$, and nd to $2.24 \mathrm{mg} / \mathrm{kg}$ for $\mathrm{HCH}$-total. The mean concentration and standard deviation were $0.017 \pm 0.011 \mathrm{mg} / \mathrm{kg}$ for $\mathrm{HCB}$, and $0.579 \pm$ $0.747 \mathrm{mg} / \mathrm{kg}$ for $\mathrm{HCH}$-total, contributing the $\gamma$ isomer with the highest values, $0.72 \pm 0.76 \mathrm{mg} / \mathrm{kg}$. Mean levels of $\alpha$ and $\beta-\mathrm{HCH}$ isomers were $0.055 \pm 0.035 \mathrm{mg} / \mathrm{kg}$, and 0.175
Table 4

Mean concentration \pm R.S.D. $(\mathrm{mg} / \mathrm{kg}$ ) and frequency of detection (\%) in Portuguese and Valencian honey samples

\begin{tabular}{llcccc}
\hline Pesticides & \multicolumn{2}{l}{ Mean concentration \pm S.D. } & & \multicolumn{2}{c}{ Frequency of detection } \\
\cline { 2 - 3 } & Spain & Portugal & & Spain & Portugal \\
\hline$\alpha-H C H$ & $0.055 \pm 0.035$ & $0.141 \pm 0.072$ & & 8 & 50 \\
HCB & $0.017 \pm 0.011$ & $0.09 \pm 0.116$ & & 12 & 54.2 \\
$\beta$-HCH & $0.175 \pm 0.078$ & $0.656 \pm 1.05$ & & 8 & 45.8 \\
$\gamma$-HCH & $0.72 \pm 0.76$ & $1.30 \pm 1.17$ & & 36 & 66.7 \\
$p, p^{\prime}$-DDE & nd & $0.186 \pm 0.25$ & & 0 & 25 \\
$p, p^{\prime}$-DDD & nd & $0.065 \pm 0.007$ & & 0 & 8.3 \\
$o, p^{\prime}$-DDT & nd & $0.06 \pm 0$ & & 0 & 4.2 \\
$p, p^{\prime}$-DDT & nd & $0.065 \pm 0.007$ & & 0 & 8.3 \\
HCH-total & $0.579 \pm 0.747$ & $1.357 \pm 1.30$ & & 48 & 91.6 \\
DDT-total & nd & $0.143 \pm 0.193$ & & 0 & 41.75 \\
\hline
\end{tabular}

$\pm 0.078 \mathrm{mg} / \mathrm{kg}$, respectively. Samples from Portugal showed higher levels. Levels of HCB ranged from nd to $0.39 \mathrm{mg} / \mathrm{kg}$. $\mathrm{HCH}$-total ranged from nd to $4.86 \mathrm{mg} / \mathrm{kg}$. Figs. 1 and 2 show the chromatograms of spiked sample and Portuguese sample obtained by GC-ECD and GC-MS, respectively. Mean concentration and standard deviation were $0.09 \pm 0.116 \mathrm{mg} / \mathrm{kg}$ for $\mathrm{HCB}, 1.357 \pm 1.30 \mathrm{mg} / \mathrm{kg}$ for $\mathrm{HCH}$-total, contributing the $\gamma$ isomer with the highest values, $1.30 \pm 1.117,0.656 \pm$ $1.05 \mathrm{mg} / \mathrm{kg}$ for $\beta-\mathrm{HCH}$, and $0.141 \pm 0.072 \mathrm{mg} / \mathrm{kg}$ for $\alpha-\mathrm{HCH}$. $p, p^{\prime}-D D T$ is released into the environment and begins to degrade and can be found in isomers, $o, p^{\prime}$-DDT, and analogous, $p, p^{\prime}$-DDE, its main metabolite and the most persistent one, and $p, p^{\prime}$-DDD. DDT-total ranged from nd to $0.658 \mathrm{mg} / \mathrm{kg}$ and its mean concentration and standard deviation were $0.143 \pm$ $0.193 \mathrm{mg} / \mathrm{kg}$, presenting DDE the highest mean level, 0.186 $\pm 0.25 \mathrm{mg} / \mathrm{kg} . p, p^{\prime}$-DDD and $p, p^{\prime}$-DDT were found both at $0.065 \mathrm{mg} / \mathrm{kg}$, with SD 0.007 . $o, p^{\prime}$-DDT was at $0.06 \pm$ $0 \mathrm{mg} / \mathrm{kg}$.

Frequency of detection was also lower in Valencian samples. Alfa and $\beta-\mathrm{HCH}$ were found in 2 samples $(8 \%), \mathrm{HCB}$ in $3(12 \%)$, and $\gamma$ isomer in $9(36 \%)$, and $\mathrm{HCH}$-total in 12 (48\%). In Portuguese samples, $\mathrm{HCH}$ isomers presented the highest frequency of detection, $16(66.7 \%), 12(50 \%)$, and $11(45.8 \%)$ samples, for $\gamma-, \alpha-$, and $\beta-\mathrm{HCH}$, respectively. HCB was detected in 13 (54.2\%) samples. Among DDT, isomers and analogous, DDE was the most frequently detected, $6(25 \%)$ samples, followed by $p, p^{\prime}$-DDD and $p, p^{\prime}$-DDT, both

Table 3

Recoveries obtained at two fortification levels, LOD, and LOQ for method 1 in honey [mean \pm R.S.D. (\%) $(n=3)$ ]

\begin{tabular}{|c|c|c|c|c|c|c|c|c|}
\hline Pesticide & $\begin{array}{l}\text { Fortification } \\
\text { level }(\mu \mathrm{g} / \mathrm{kg})\end{array}$ & Method 1 & $\begin{array}{l}\text { Fortification } \\
\text { level }(\mu \mathrm{g} / \mathrm{kg})\end{array}$ & Method 1 & $\begin{array}{l}\text { LOQ }(\mathrm{mg} / \mathrm{kg}) \\
\text { GC-ECD }\end{array}$ & $\begin{array}{l}\text { LOD }(\mathrm{mg} / \mathrm{kg}) \\
\text { GC-ECD }\end{array}$ & $\begin{array}{l}\text { LOQ }(\mathrm{mg} / \mathrm{kg}) \\
\text { GC-MS }\end{array}$ & $\begin{array}{l}\mathrm{LOD}(\mathrm{mg} / \mathrm{kg}) \\
\text { GC-MS }\end{array}$ \\
\hline$\alpha-\mathrm{HCH}$ & 25 & $82 \pm 10$ & 50 & $64 \pm 6$ & 0.03 & 0.004 & 0.01 & 0.003 \\
\hline $\mathrm{HCB}$ & 10 & $110 \pm 8$ & 20 & $78 \pm 10$ & 0.01 & 0.004 & 0.02 & 0.006 \\
\hline$\beta-\mathrm{HCH}$ & 50 & $68 \pm 21$ & 100 & $74 \pm 10$ & 0.06 & 0.001 & 0.01 & 0.002 \\
\hline$\gamma-\mathrm{HCH}$ & 25 & $82 \pm 10$ & 50 & $143 \pm 1$ & 0.05 & 0.001 & 0.01 & 0.003 \\
\hline Aldrin & 50 & $111 \pm 31$ & 100 & $75 \pm 23$ & 0.06 & 0.005 & 0.02 & 0.006 \\
\hline$p, p^{\prime}-\mathrm{DDE}$ & 50 & $77 \pm 6$ & 100 & $80 \pm 6$ & 0.06 & 0.01 & 0.04 & 0.01 \\
\hline$p, p^{\prime}-\mathrm{DDD}$ & 50 & $86 \pm 16$ & 100 & $91 \pm 19$ & 0.06 & 0.01 & 0.04 & 0.01 \\
\hline$o, p^{\prime}$-DDT & 50 & $85 \pm 22$ & 100 & $81 \pm 12$ & 0.06 & 0.02 & 0.04 & 0.01 \\
\hline$p, p^{\prime}-\mathrm{DDT}$ & 100 & $126 \pm 17$ & 200 & $71 \pm 2$ & 0.10 & 0.01 & 0.04 & 0.01 \\
\hline
\end{tabular}



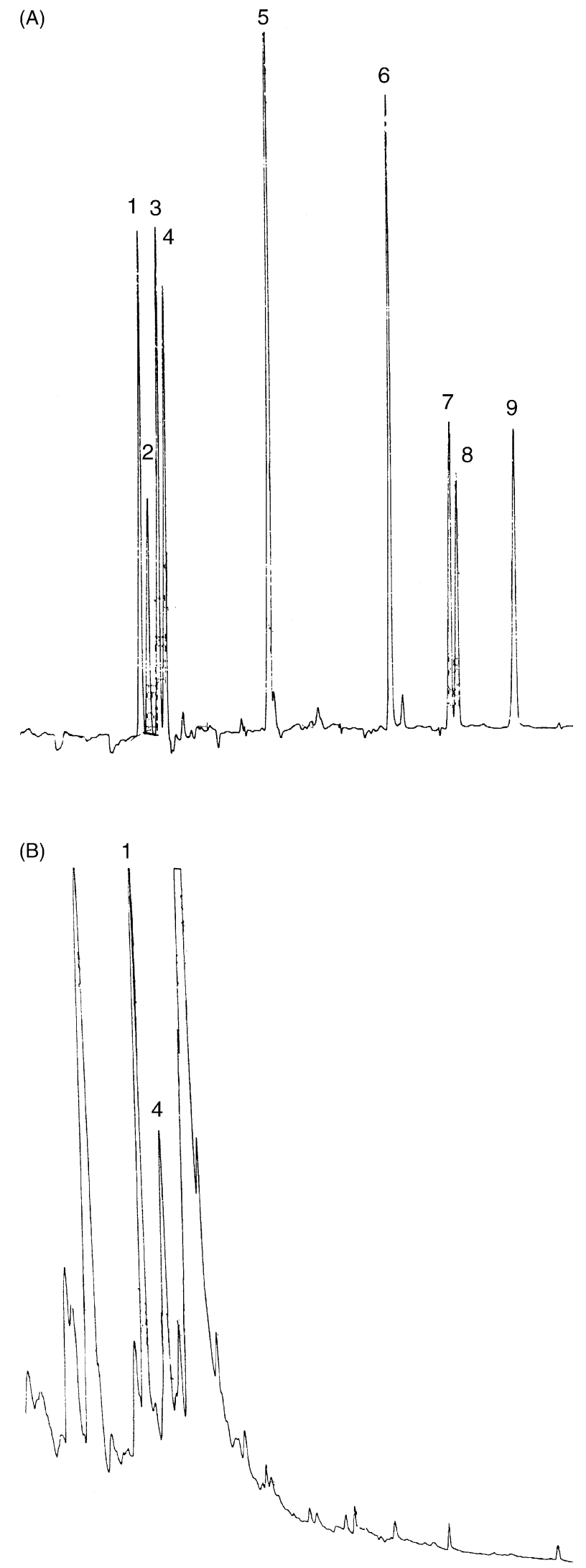

Fig. 1. GC-ECD chromatograms of (A) untreated honey sample spiked at five times the LOQ (peak identification as Table 2), and (B) a P14 honey sample that contains $0.27 \mathrm{mg} / \mathrm{kg}$ of $\alpha-\mathrm{HCH}$ and $0.05 \mathrm{mg} / \mathrm{kg}$ of $\gamma-\mathrm{HCH}$.
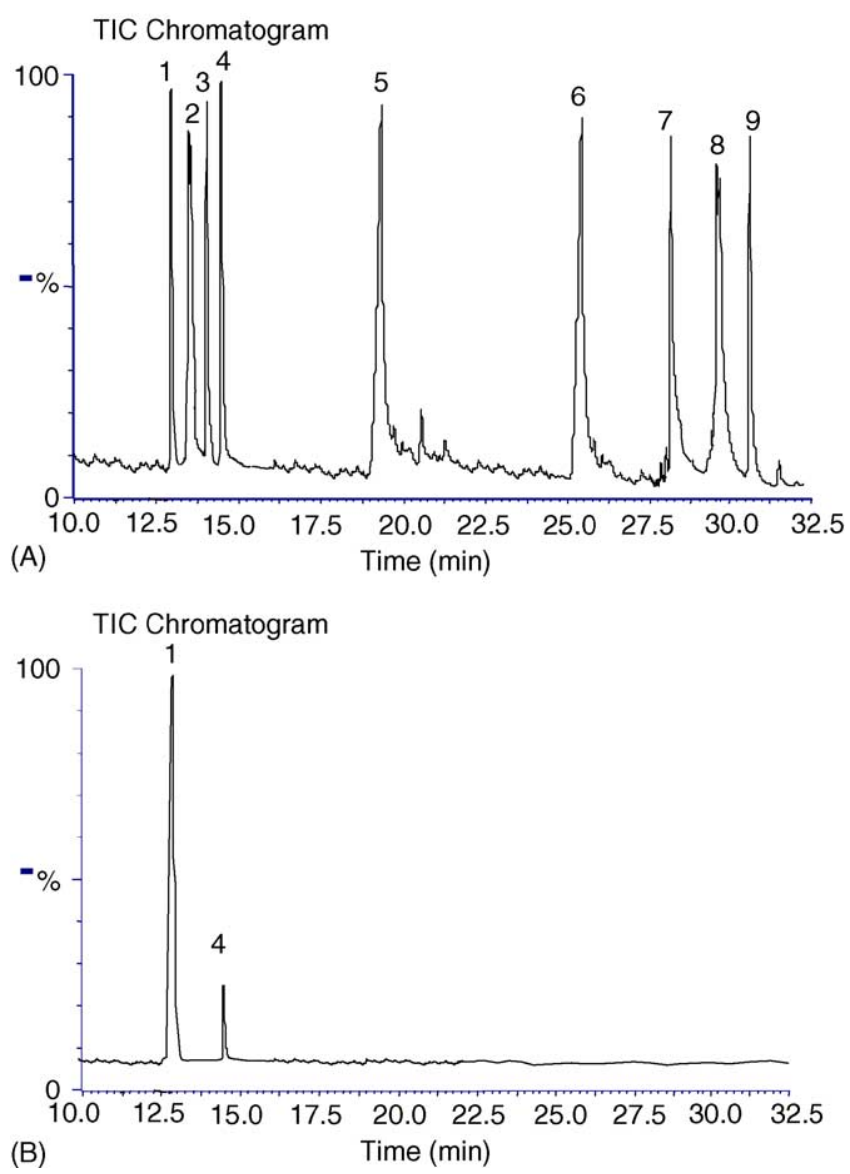

Fig. 2. Total ion current GC-MS chromatograms of (A) untreated honey sample spiked at five times the LOQ (peak identification as Table 1), and (B) a P14 honey sample that contains $0.27 \mathrm{mg} / \mathrm{kg}$ of $\alpha-\mathrm{HCH}$ and $0.05 \mathrm{mg} / \mathrm{kg}$ of $\gamma-\mathrm{HCH}$.

with $2(8.3 \%)$, and $o, p^{\prime}$-DDD with $1(4.2 \%)$ sample. DDTtotal was detected in $10(41.75 \%)$ samples, while $22(91.6 \%)$ samples had HCH-total.

According to European Union (EU) Regulations, honey as a natural product, must be free of any chemical contaminants and safe for human consumption [18]. On this basis, only 12 samples are agreed with this regulation, one from Portugal, and eleven from Spain.

\section{Conclusions}

The present procedure, which involves a rapid and liquid-liquid extraction with ethyl acetate and GC-ECD and GC-MS, requires less solvent than the traditional ones and a small amount of sample $(4 \mathrm{~g})$, with the consequent reduction in co-extracts, and provides satisfactory recoveries, repeatability and reproducibility.

The described method has used to evaluate contamination of honey samples from central zone of Portugal and Valencian community in Spain, and it was clear than levels of OCPs studied are higher in Portuguese samples. 


\section{Acknowledgments}

This work was supported by the FCT, POCTI (FEDER), and the Integrated Actions Programme between Portugal and Spain, E-7/02 and HP2001-0009.

\section{References}

[1] C.M. Lino, L. Guarda, M.I. Silveira, J. AOAC Int. 82 (1999) 1206.

[2] S. Cruz, S.C.M. Lino, M.I. Silveira, Sci. Total Environ. 317 (2003) 23.

[3] C.M. Lino, A. Pena, M.I. Silveira, in: C. Borrego, C. Coelho, L. Arroja, C. Boia, E. Figueiredo, (Eds.), 5a Conferência Nacional sobre a Qualidade do Ambiente, vol. 2, University of Aveiro, 1996, p. 1587.

[4] Y. Picó, E. Viana, G. Font, J. Mañes, J. Agric. Food Chem. 43 (1995) 1610.
[5] M.A. Fernandez-Muiño, M.T. Sancho, S. Munitegui, J.F. Huidobro, J. Simal-Lozano, J. Food Protect. 58 (11) (1995) 1227.

[6] B. Marzycka, J. Chromatgr. A 982 (2002) 267.

[7] M. Fernández, Y. Picó, J. Mañes, J. Food Protect. 65 (2002) 1502.

[8] D. Tsipi, M. Triantafyllou, A. Hiskia, Analyst 124 (1999) 473.

[9] A. Rathi, B. Kamari, S.K. Gahlawat, R.C. Sihag, T.S. Kathpal, Pestic. Res. J. 9 (1997) 226.

[10] M.R. Driss, M. Zafzouf, S. Sabbah, M.L. Bouguerra, Int. J. Eviron. Anal. Chem. 57 (1994) 63.

[11] M.A. Fernández Muiño, J. Simal Lozano, Analyst 116 (1991) 269.

[12] J. Jan, K. Černe, Bull. Environ. Contam. Toxicol. 51 (1993) 640.

[13] A. Rifai, N. Akeel, J. Apicult. Res. 36 (1997) 155.

[14] J.J. Jiménez, J.L. Bernal, M.J. Del Lozal, L. Toribio, M.T. Martín, J. Chromatogr. A 823 (1998) 381.

[15] C. Jansson, J. AOAC Int. 83 (2000) 714.

[16] J.J. Jiménez, J.L. Bernal, M.J. Del Lozal, L. Toribio, M.T. Martín, A.L. Mayorga, J. Chromatgr. A 829 (1998) 269.

[17] C. Lino, C.B. Azzolini, D.S. Nunes, J.M. Silva, M.I. Silveira, J. Chromatogr. B 716 (1998) 147.

[18] EEC Directive, 74/409, 1974. 